\title{
John Heartfield'ın "Bașkalașım” Adlı Fotomontajında Yer Alan Metaforik Yapılanma Üzerine Göstergebilimsel Çözümlemeler
}

\author{
Meral BOSTANCI*
}

özet

Alman sanatçı John Heartfield (1891-1968), 20. yüzyılın politik sanatçılarının önde gelenlerinden ve günümüzde ‘photoshop' olarak bilinen modern fotomontaj tekniğinin öncülerinden biridir. Bu çalışmanın amacı John Heartfield'ın en bilinen yapıtlarından biri olan "Başkalaşım” (Alm. Metamorphose) adlı fotomontaj çalışmasını çözümlemeye yöneliktir. Göstergebilimsel yaklaşımın kimi verilerden faydalanarak ve tablolarla harmanlayarak sunacağımız bu çalışmada yeri geldiğinde metinlerarası ve göstergelerarası ilişkilendirilmelere de yer verilerek çoğul bir okuma yapılması hedeflenmektedir. Bu bağlamda öncelikle imgeler, simgeler ve alegoriler üzerinden çalışmada var olan metaforik yapılanmayı çözümlemek, devamında yapıtın ve sanatçının içinde bulunduğu kültür kodları da çalışmaya dâhil edilerek yapıtı yorumlamak temel esas olacaktır.

Anahtar Sözcükler: John Heartfield, Fotomontaj, Başkalaşım, Metafor, İmge, Göstergebilim, Göstergelerarasılık.

\section{Artistic Imagination as a Political Discourse Tool. Instance of John Heartfield. A Semiotic Analysis Of The Metaphorical Structure Of John Heartfield's Photomontage, "Metamorphosis"}

\section{Abstract}

The German artist John Heartfield (1891-1968), was a prominent twentieth century political artist and one of the pioneers of modern photomontage, or photoshopping, as it is better known today. This study analyzes "Metamorphosis" (Metamorphose" in its German origin), one of John Heartfield's best known photomontages. This study employs the tools of semiotic analysis, interspersed with figures and aims to present a plural reading by making appropriate intertextual and intersemiotic connections. Within this framework, imagery, symbols and allegories will be analyzed to expose the work's metaphorical structure, and then an interpretation will be made with reference to the cultural codes of the artist and the work.

Keywords: John Heartfield, Photomontage, Metamorphosis, Imagery, Semiotics. Intersemiotics 


\section{Giriş:}

Berlin Dada hareketinin kurucu üyeleri arasında adı anılan John Heartfield ${ }^{1}$, kendi dönemine göre oldukça yeni olan fotomontaj tekniklerini kullanarak gerçeküstü değerde resimler yaratmaya çalışmıştır. 20. yüzyılın geçirdiği iki büyük dünya savaşına tanıklık etmiş ve en çalkantılı dönemlerinde yaşamış bir sanatçı olarak politikaya olan aşırı ilgisi rastlantı değildir. Dönemin getirdiği buhranların halka verdiği yıkımı ve zararı gören bütün duyarlı sanatçılarda olduğu gibi Heartfield de savaşa karşı muhalif bir tavır takınmış ve bu duruşu onu savaş karşıtı çalışmalar yapmaya yöneltmiştir. Kuruluşunun ilk gününden itibaren Alman Komünist Partisi (Kommunistische Partei Deutschland/ KPD) üyesi olan sanatçının kendi ideolojik yöneliminin de etkisiyle Birinci ve İkinci Dünya Savaşı'na yol açan siyasi liderleri ya da onların politikalarına akıllı ve keskin eleştiriler ileten metamorfik görüntüleri araç olarak kullanarak bir takım metaforik anlamlar ürettiği görülmektedir. Sanatçı hayvanlara, böceklere veya onların organlarına, çağrışımsal bağları nedeniyle sıklıkla başvurmuş ve birçok yapıtında bu görüntülere yer vermiştir. Bu durum gittikçe siyasi bir söylem aracına dönüşmüş; sanat onun için bir amaç değil, araç haline gelmiştir. Çalışmanın odak noktasına konumlandırılmış olan Başkalaşım (Metamorphose) adlı fotomontaj Heartfield'ın söz konusu tutumuna çarpıcı bir örnek niteliğindedir.

Heartfield çalışmalarında genellikle ikili anlamlar içerecek şekilde görüntüleri yan yana yerleştirir. Sanatçının başarısının, bu çifte anlamlılığın algıda açtığı gediklerden kaynaklandığını söylemek mümkündür (Zervigon, 2007:4). Fotomontaj tekniğinin ve özellikle politik fotomontajın 20. yüzyıl Avangart sanatına Berlin Dada hareketinin katkıları sayesinde girmiş olduğu söylenebilir. Siyasal tarih içinde Berlin Dada, fotomontajı, Zürih Dada'dan daha keskin bir hiciv formu olarak kullanmış ve bu tekniklerle Weimar Cumhuriyeti'ne yönelik aktivist muhalefetin temelini oluşturmuştur. Nitekim birçok sanat kuramcısı ve siyaset bilimcisi Dada hareketinin Berlin'deki sol kanat temsilcileri arasında bulunan John Heartfield'i politik amaca yönelik sanatsal etkinlikleriyle ve bu amaca yönelik düzenlediği fotomontajlarla öne çıkan bir sanatçı olarak tanımlamışlardır.

Genel olarak kolaj ve fotomontaj tekniği resimli dergilerden, gazetelerden ya da eski mektuplardan kesilen fotoğraf ve yazı gibi hazır nesnelerin yeniden düzenlenerek belli bir yüzey üzerine yapıştırılması olarak tanımlanır. Öte yandan bu düzenlemelere el yazısı, desen ve boyama teknikleri ile müdahalelerde bulunulduğu da görülür. Kolaj ve fotomontaj tekniği aracılığıyla birbirleriyle ilgisi olmayan resim ve işaret parçalarından yeni anlamlar ve yeni bağlantılar kurulur. Görüntülerde yapılanan yeni simgeler, kodlar ve metaforlar bir bütün olarak düşünüldüğünde üretilen düzenlemenin imgesel olarak genellikle sanatın karşıt, muhalif ve kışkırtıcı alanında yer alması kaçınılmazdır. Kültür tarihçisi Prof. Graham Dawson'ın (1956) tanımladığı biçimiyle bu tip görüntü düzenleri ya da eleştirel kurgular belirli bir kültürde herhangi bir anda kamusal olarak mevcut olan ve aslen onun ruhsal ve toplumsal boyutlarını dile getiren bir dizi izlek, imge, motif ve anlatı biçimleridirler (Anker, 2011: 43-44) ${ }^{2}$. Heartfield'ın Başkalaşım ya da Dönüşüm olarak tanımlanabilecek fotomontajı da benzer örüntülerle düzenlenmiş, politik imgelemiyle dikkat çekici bir çalışmadır. Ortaya çıkan ürün sıra dışı görünüyor olsa da burada kullanılan dilin, tasarlanan imgeyi ${ }^{3}$ daha güçlü kıldığı açıktır. Bu çalışmada hedeflenen iki dünya savaşı arasında bulunduğu Almanya'da dönemin politik süreçlerinin aktif bir katılımcısı olan sanatçı Heartfield'ın siyasi bir söylem aracı olarak sanatını kullanmasına aracılık eden iktidar muhalifi imgelerine, alegori/simge/metafor/ bağlamında çıkarsamalarda bulunmak ve söz konusu çalışmanın anlam yapısı üzerine göstergebilimin sağladığı veriler doğrultusunda çözümlemeler üzerinden içsel bir okuma yapmak olarak özetlenebilir.

\section{“Başkalaşım” (Metamorphose):}

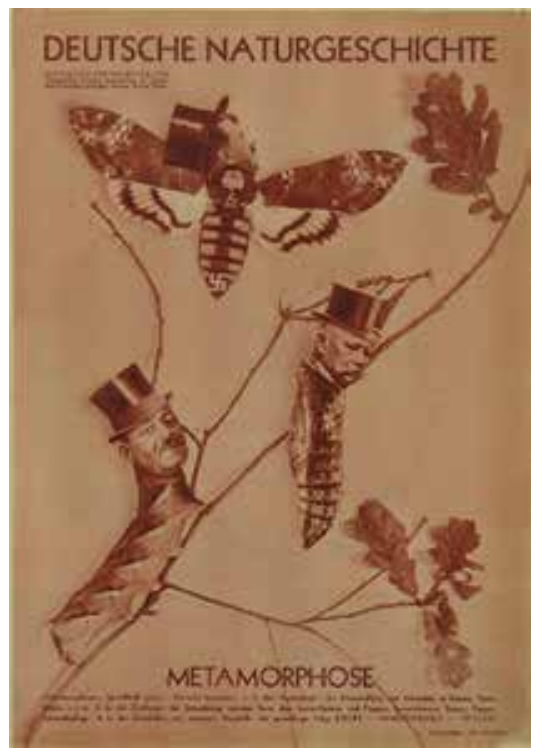

Resim 1. John Heartfiled, “Alman Doğa Tarihi, Başkalaşım” (Alm. Deutsche Naturgeschichte, Metamorphose / İng. German Natural History, Metamorphosis), 38,1x 25,4 cm., 16 Ağustos 1934, AIZ, Prag. Alman ölüm güvesinin üç gelişim aşaması: Kurtçuk-krizalitgüve: Ebert-Hindenburg-Hitler (Pachnicke\&Honnef, 1992:165). 
Yapıtın adı dilimize "Metamorfoz" (Alm. Metamorphose, Ing. Metamorphosis, Fr. Métamorphose) olarak geçmiş ve "Başkalaşım”, “Başkalaşma”, “Değişim” ya da “Dönüşüm” olarak çevrilmiştir. "Metamorfoz" bu çalışmanın anahtar sözcüğüdür. Çalışmanın adı olmasından ötürü içerdiği kavramlar öncelikle bu kilit sözcük ve onun psişik uyarımı üzerine anlam kazanacaktır. "Başkalaşım" sözlük anlamı itibariyle mitolojide insanların ağaç, hayvan, taş ve bunun gibi başka bir nesneye dönüşmesi, zoolojide ise hayvanların bazılarının larvadan, krizalitten, kurtçuk ve kelebeğe ya da güveye olan evrimlerini anlatmak için kullanılan bir terimdir (Aktaran: Bostancı, 2012: 436).

Öte yandan dönüşüm veya başkalaşım olgusu mitolojide sıklıkla kullanılmış ve efsanelere konu olmuş bir kavramdır. Başkalaşımı mitolojik anlamıyla tanımlamak istersek, mitolojik efsanelerde bahsi geçen karakterin çoğunlukla geri dönüşü olmayan büyük ve geri alınamayan metamorfik (Fr. Métamorphique) değişiminden bahsetmemiz gerekir. Bilindiği gibi klasik mitoloji külliyatı, klasik ve sonrası dönemde edebiyatçılara yorumlama ve esinlenme adına oldukça verimli kaynakçalar bırakmıştır. Latin ve Ortaçağ Edebiyatı boyunca anlatımında görece değişiklik olmamış genç avcı Actaeon'un öyküsü buna örnek verilebilir. Acteon'un öyküsü özünde, ani bir fiziksel değişim üzerinden kendine dayanak bulan saldırı ve cezalandırma kavramlarının dürüst bir hikâyesidir. Efsanenin en bilinen versiyonu Romalı Büyük Şair Ovid'in (Publius Ovidius Naso, M.Ö. 43-M.S. 17) Metamorfoz'unda anlatılan Tanrıça Diana ile ilgili olanıdır. Tanrıça gün ortasında dinlenirken Actaeon yanlışlıkla onun mağarasına girer. Diana onu bir geyiğe çevirerek öfkesini gösterir. Bundan sonrasında efsane, bu geyiğin takibi ve geyiğe dönüşmüş Actaeon'un kendi av arkadaşlarının kışkırtmasıyla bizzat kendi köpekleri tarafından yakalanıp parçalanmasının uzun uzadıya anlatılması ile devam eder (Hawes, G. 2006: 21). ${ }^{4}$

Meseleye daha geniş açıdan bakan edebiyat eleştirmeni Pierre Brunel'e (1939) göre ise başkalaşım (Metamorphose), ne bir türün değişimi konusuna indirgenebilir ne de bir iktidarın değişimidir. 0 sadece doğumdan önce ve ölümden sonraki zaman dilimine yönelik bir hipotezdir; ruh ve beden arasındaki sınırları ise oldukça net ve kesindir (Brunel, 2004: 155). Bu tanımlamalar daha da genişletilebilir.

\section{Yöntemsel Yaklaşım:}

“İnancı açıklığa kavuşturmak için akla, aklı açıklığa kavuşturmak için imgeleme başvurmayı gerekli gören anlayış, imgelemi açıklığa kavuşturmak için de duyulara başvurmuştur (Panofsky, 1995: 27). Komünist Parti'ye olan inancını her fırsatta dile getiren Heartfield henüz yeni sayılabilecek bir sanat biçemi olan fotomontaj tekniğini kullanarak üretmiş olduğu yapıtlarıyla partisine büyük katkılarda bulunmuştur. KPD’ye yürekten bağlı olan sanatçı kendi ideolojik tavrını düzenlediği montajlarla ortaya koymuş, halkın duyularına hitap ettiği çalışmalarıyla partisinin kitlelere ulaşan sesi olmuştur. İncelemeye konu olan çalışmasına (Resim 1) baktığımızda Heartfield'ın Başkalaşım'ını teknik açıdan çeşitli fotoğraf parçalarının ve resimlerin manuel düzenleme ile üst üste ya da yan yana yapıştırılması suretiyle oluşturulmuş karışık teknik bir kolaj çalışması olarak sınıflandırabiliriz. Yapılan düzenlemenin bir gazete aracılığıyla reprodüksiyonu yapılarak binlerce adet basıldığı ve bunların halka dağıtıldığı düşünüldüğünde toplumsal bir gönderge ile karşı karşıya bulunulduğu açıktır. Düzenlemede görsel göstergelerin yanı sıra dilsel bir takım sloganlar da bulunmaktadır; yazınsal eklemleme ve düzenlemede yer alan sıra dışı kurgulanımıyla izleyicisine adeta bir şeyler söylemek istemektedir. Yapıt, yoğrumsal bir biçimden daha ağır basan içeriksel bir biçemle kuşatılmıştır ve izleyici, kendisini sorgulamaya yönlendiren etkili bir anlatı dizgesi ile karşı karşıyadır.

Anlatı çözümlemeleri, tümdengelimli bir yöntemi benimsemek zorundadır; önce varsayımsal bir betimleme örnekçesi (kuram) tasarlamak, sonra da bu örnekçeden yola çıkarak hem kendisine uyan hem de ayrılan türlere doğru inmek durumundadır (Barthes, 1988: 10-11). Tüm bu olgulardan hareketle çalışmada kuram ya da yöntemsel izlek olarak 1930'lu yıllarda Warburg Çalışmaları ile ikonolojiyi sanat tarihinde bir yöntem olarak oluşturan sanat tarihçi ve estetikçi Erwin Panofsky'nin (1892-1968), “İkonografi ve İkonoloji” üzerine belirlediği yöntemin önerilerini uygulamayı uygun gördük. Panofsky, 19. yüzyılın sonlarından itibaren bir bilim olarak sanat tarihinin ilkelerini ortaya koyan Giovanni Morelli (1816-1891), Alois Riegl (1858-1905) ve Heinrich Wölffin (1864-1945) gibi ilk kuşak sanat tarihçilerinin öğrencisi olarak yetişmiştir. Bu kuşağın en önemli ismi Wölfflin'in kuramı, bilindiği gibi sanat yapıtlarının sadece biçimsel çözümlememesine (Rönesans ve Barok açısından) olanak verir. Panofsky, Wölfflin'in düşüncelerine getirdiği eleştirilerle sanat yapıtlarının çözümlenmesi 
ve yorumunun sadece biçime yönelik ve salt optik olarak algılanan formlarla açıklanamayacağını söyler. Onun görüşüne göre sanat yapıtı yaratıldığı ortamdan soyutlanamaz. İçinde bulunduğu ve bir parçası olduğu kültür ortamı içerisinde yani dönemin felsefesi, toplumsal yapısı, psikolojisi, dinsel ortamı, politik ve ekonomik durumu gibi olguların tamamı ile birlikte ele alınıp incelenmesi gerekir. Panofsky bu olguların hepsini "kültürel belirtiler" (cultural symptoms) olarak adlandırmıştır (Panofsky, 1995a: 9-11).

Panofsky’nin 'ikonografik' yönteminde öncelikle sanatsal motiflerin bulunduğu pratik deneyimlere dayanan olgusal ve anlatımsal bir ilk süreç bulunur. Panofsky bu evreye “Ön-İkonografik Betim” demektedir (Panofsky, 1995a:48). Yapıtın söz konusu ön betini için pratik yaşamdan elde edilen deneyler yeterlidir. Bir sonraki aşamada yapıtı tam anlamıyla çözümlemek için sanatsal motiflerle birlikte kimi kaynaklar, metinler ya da kavramlar arasında bir bağ, bir ilişki kurulması gerekir. Panofsky'e göre bu anlama ulaşabilmek günlük pratik deneyimlerimizin dışına çıkmakla, onları başka bilgilerle tamamlamakla mümkündür (Cömert, 1999: 13). Panofsky, imgelerin, alegorilerin ve öykülerin anlatıldığı bu süreci "İkonografik Çözümleme” olarak adlandırır. Bunun için yazınsal kaynakların bilinmesi, değişik tarihsel koşullar içinde özgül tema ile kavramların nesneler ve olaylar aracılığıyla anlatılış tarzının incelenmesi gerekir. Son aşama yani bir resim yapıtını algılama evrelerinin sonuncusu, onun 'asıl anlamı, içsel anlamı veya içeriği’ sorunsalıdır. Panofsky bu sürece "İkonolojik Yorum” adını vermiştir. Panofsky’nin kültürel belirtiler yani genel olarak 'simgeler tarihi' olarak tanımladığı olgu, bu son evrenin konusunu oluşturur (Panofsky, 1995a:48). Panofsky'nin 'simgesel değerler dünyası' olarak açımladığı bu kısma dair sanat tarihçi, akademisyen, yazar ve çevirmen Bedrettin Cömert (1940-1978) şunları söylemiştir:

“...Bir resim yapıtının içeriği, başka bir deyişle asıl anlamı, bir ulusun, bir dönemin, bir sınıfın, bir dinsel veya felsefi anlayışın, bir sanatçı kişiliği tarafından nitelenmiş ve bir yapıtta yoğunlaşmış temel davranışını belirten temel değerlendirmesi, insanlığın ulaştığı düşünce ve beğeni aşamasındaki yerinin belirlenmesi, yani gerçek anlamda algılanıp, estetik bir bütünlük içinde yaşanılması, insanın öteki etkinlikleriyle uyum içinde bir ilişkiye sokulmasının sağlanması için uygulanan işleme ikonolojik yorum adı verilir." (Cömert, 1999:14)
Bu bağlamda Panofsky’nin önerdiği yöntemsel izlekten hareketle göstergebilimsel yöntemin son aşamasında içsel anlam ya da içerik yorumlamasına gidilerek, söz konusu temel ilkelerin saptanmasına çalışılacaktır. Bunu yaparken yapıtın sunduğu imgelerden hareketle düz bir okumanın yanında gönderdiği kavrama dair içerik okuması zorunludur. Tam bu noktada "düzenlam/yananlam” olgularına değinmek gerekiyor: İlk olarak Kopenhag Dilbilim Çevresi'nin kurucuları arasında yer alan Louis Hjelmslev'in (1899-1965) ortaya koyduğu düzanlam ve yananlam kavramları, bir göstergenin iki farklı değeri olarak ortaya çıkmıştır (Rifat, 2008:125). Roland Barthes'ın (1915-1980) Hjelmslev'den alarak geliştirdiği bu kavramda her anlamlama dizgesinin bir anlatım düzlemi (düzanlam, gösteren) ile bir içerik düzlemini (yananlam, gösterilen) kapsadığı ve anlamlamanın bu iki düzlem arasındaki bağıntıya eşit oluştuğu yönündedir (Barthes, 1979: 87).

Öte yandan bu çalışmanın 1980 Paris Göstergebilim Okulu temsilcilerinden A. J. Greimas’ın (1917-1992) önerdiği 'söylemsel' göstergebilim kurallarını da içerdiğini belirtmek gerekiyor. Greimas'ın yaklaşımı da hem yazınsal dizgeleri hem de yazınsal olmayan görsel dizgeleri kapsamaktadır. Greimas öğretisi, insanın yarattığı anlam taşıyan yapıların evrensel özellikleriyle birlikte kişiden kişiye, toplumdan topluma değişen özelliklerini, yüzeysel yapılarından derin yapılarına inen bir yaklaşımla analiz etmektedir (Kıran ve Kıran 2001: 290). Greimasçı göstergebilimde anlamın oluşumu yine üç aşamalı bir yapı olarak sunulmuş ve betimsel, anlatısal ve izleksel düzey olarak adlandırılmıştır (Günay, 2012: 38-39). $\mathrm{Bu}$ çalışmada hedeflenen, politik yapıtlarıla ün salan John Heartfield'ın Başkalaşım (Metamorphose) adını verdiği fotomontaj metninin bize iletmek istediği siyasi içeriğe ulaşmak adına Panofsky’nin ikonografik yönteminin yanı sıra ona benzer bir yaklaşım sunan ve yukarıda kısaca açımlanan Greimas göstergebilim ilkelerinden yeri geldiğinde yararlanmak suretiyle "düzanlam ve yananlam" olgularını da kapsayan detayl bir okuma yapmaktır.

\section{Ön-İkonografik Betim:}

Yüzeysel yapıda ilk bakışta resmin yüzeyinde diyagonal bir çizgisellik oluşturan ağaç dalı ile dalın üzerine ve/veya çevresine konumlandırılmış üç adet birbirine benzer yarı insan yarı hayvan (böcek) imgeleri göze çarpmaktadır. Bunlardan ilki resmin sol bölümünde, yaprağı nedeniyle meşe ağacının dalı olduğu anlaşılan dal üzerinde başı insan başı şeklinde ve 
izleyiciye dönük halde durmuş, gövdesi ise bir kurtçuk olarak "yarı insan yarı hayvan" imgesidir. Resmin sağında ise aynı dala asılı, gözleri tamamen kapalı, adeta uyur halde bir imge daha bulunur. Başı insan ancak gövdesi bu kez krizalit şeklinde betimlenmiştir. Son olarak resmin üst kısmında ve ortada, havada, dalla ilişiği kalmamış, uçar halde, yine başı insan ancak gövdesi güve olarak betimlenmiş bir başka imge daha verilmiştir. Bilindiği gibi bu betimlemeler, sanat yapıtının biçimsel olarak algılanmasına yönelik, birincil ya da doğal anlam katmanlarının oluşturduğu ön betimlemenin yapıldığı; nesnelerin en yalın biçimleriyle tanımlandığı aşamadır ve çaıışmanın ilk adımını oluşturur. Yukarıdaki ifadeler bir bakıma düz bir anlatıma yöneliktir ve Barthes'ın deyişiyle tamamen “düzanlamsal” bir okumadır. Yazınsal göstergebilim, tiyatro göstergebilimi, metin dilbilim ve söylem çözümlemesi gibi alanlarda ülkemizdeki yetkin akademisyen, dilbilimci ve yazar Doğan Günay’ın da belirttiği gibi: “Her imge öncelikle düzanlamsal okunur” (Günay, 2012: 29).

Ön-ikonografik betim ya da yarı biçimsel çözümlemeye devam edildiğinde hem resmin alt kısmında yer alan yazılar yardımıyla hem de gösterilen insan başları aracılığı ile izleyici öznenin belleğinde bilinen, tanınan kişiliklere bir gönderme yapılmaya çalışıldığı anlaşılır. Sözceleyenin (Heartfield), sözcesi (yapıt) üzerinden, sözceye verdiği ad (Alman Doğa Tarihi, Başkalaşım) ve sözceye eklemlenmiş slogan (Weimar Cumhuriyeti'nde Alman ölüm güvesinin üç gelişim aşaması: EBERT-HINDENBURG-HITLER) aracılığı ile çizgisel bir sıralamaya gönderme yapmak istediği anlaşılır. Sanatçının sloganı aracılığıyla, Weimar Cumhuriyeti siyasal tarihinde EbertHindenburg-Hitler'in art arda ülke yönetiminde üç değişik gelişim aşaması ile iktidara gelmelerini, doğa tarihinde bir evrim olan kurtçuk-krizalit-güve oluşumuna benzeterek düzenlediği bir çalışma olduğunun farkına varılır.

\section{İkonografik Çözümleme:}

$\mathrm{Bu}$ doğrultudan hareketle yapılan araştırmalarla edinilen, yapıtla ilişkilendirilebilecek şu bilgiler önemlidir: Friedrich Ebert 1919-1925 döneminde Weimar Cumhuriyeti'nin ilk devlet başkanıdır. Cumhuriyetin ikinci gelişim döneminde 1925 yılında Poul von Hindenburg devlet başkanı olmuştur. Kendisi 1933 yılında siyasi erki parlamenter rejimden başkanlık rejimine geçirerek 'Enabling Act'i yani Almanya'da yetkinin tek elde toplanmasına olanak sağlayan yasayı harekete geçiren ilk kişidir. 1847 doğumlu yaşlı von Hindenburg'ün 1934'de ölümünün ardından Hitler, bu yasanın sunduğu olanaklar aracılığıyla kendini “Führer” ilan etmiş ve yürütme ile ilgili tüm erki ele geçirmiştir. Söz konusu çalışma Hindenburg’ün ölümünden sadece iki hafta sonra üretilerek ülkenin sol içerikli yayınlar yapan ve geniş bir okuyucu kitlesine sahip olan gazetesi AIZ'in (Die Arbeiter-Illustrierte Zeiung/ Resimli İşçi Gazetesi) $)^{5}$ arka kapağında tam sayfa boyutunda yayımlanmıştır. Anlaşılan o ki elimizdeki montaj Heartfield'ın ve genel olarak sol kanat muhalefetin tepkisini ortaya koymayı amaçlayan bir çalışmanın ürünüdür.

Heartfield'ın Alman Doğa tarihi imgelemine göre Alman meşesinin üzerine kondurmuş bulunduğu Friedrich Ebert, Weimar Cumhuriyeti'nin kurdu olarak ifade edilmiştir. Von Hindenburg ise meşe ağacına asılı uyuyan bir kukla gibi ve metamorfoz olgusundan hareketle, başkalaşım geçirmek üzere sertleşmiş kabuklarını yırtmak üzere olan bir krizalite benzetmiştir. Hitler'e gelince, bu dönüşümün son halkası olarak, Weimar Cumhuriyeti'nin güvesi şeklinde gösterilmiştir. Alman Doğa Tarihi'nde fotoğrafta gösterilmiş olan güve cinsi çam, kayın ve meşe gibi orman ağaçlarına büyük zararlar verebilen oldukça tehlikeli bir tür (yapıtta geçtiği haliyle Alman ölüm kelebeği / Deutscher totenkopf-falter ya da kurukafa güve / death's head moth) olarak bilinir (Bkz. Resim 2). Bu fotomontajın AIZ’de, “Alman Ölüsünün Güvesi” başlığı altında yayımlandığı düşünüldüğünde Heartfield'ın imgelemi aracılığı ile Hitler faşizminin insanlığa verdiği zararı ve tüm zorbalığına rağmen tarihteki yükseliş evrimini, ormanda yaşayan ve ormana son derece zararlı bir güvenin oluşum evresiyle betimlemeye çalıştığı açıkça görülür (Bostancı, 2012:438).

\section{İkonolojik Yorum:}

John Heartfield'ın Başkalaşım adlı çalışması, metafor ve benzetmelerin güçlü bir kombinasyonudur. Montajın konusu göründüğünün ötesinde aslen güncel, politik bir olay ile ilintilidir. Bu bağlamda göstergebilimsel yöntemin son aşaması olarak göndermede bulunulan simgeler dünyasının kodları yorumlanarak derin yapının saptanmasına çalışılacaktır. Diğer bir tanımla bu aşama yananlama ulaşılan aşamadır. Yananlam olgusu, Barthes'ın söyleminde olduğu gibi, günümüzde birçok bildiriyi aktaran kitle haberleşme araçlarıyla sıkı 
sıkıya bağlıdır: "Gazetemizi okurken, sinemaya gittiğimizde, televizyon izlerken ve radyo dinlerken, satın aldığımız ürünün ambalajına göz gezdirirken, her zaman sadece yananlamsal bildiriler alındığı ve algılandığı aşağı yukarı kesindir” (Barthes, 1993:164). Günay’a göre “yananlam ya da çağrışımsal anlamların kullanıldığı bildiriler görecelik içerir ve yorum gerektirir" (Günay, 2012: 29). Bu çalışmada da gösteren/ gösterilen kavramlarından hareketle (Hitler faşizmi ve geçirdiği evrim/ kurukafa-ölüm güvesinin geçirdiği evrim) yananlamsal olgulardan söz edilebilir. Şöyle ki: Paul von Hindenburg'ün ölümünden iki hafta önce Hitler kendini Almanya'nın Führer’i olarak ilan etmiş̧tir. Bunu gösteren "Alman Doğa Tarihi-Başkalaşım" adlı çalışmada John Heartfield'ın imgesi açık ya da örtük göndermelerle kurgulanarak Alman ulusunun gelişimini bir tırtılın kozasından çıkarak son derece zararlı bir tür güveye dönüşen yaşam süreci olarak belirir. Bu noktada söz konusu düzenleme ile ilgili destekleyici ve öngörüyü güçlendirici bir kaç araştırma yazısına yer verilecektir: UCC'da Sanat Tarihi öğretim görevlisi Dr. Sabine Kriebel’a (1970) göre:

Montaj, Friedrich Ebert'in sosyalizminden Paul von Hindenburg'ün militer muhafazakârlığına ve Hitler’in ölümle sonlanan Nasyonal (Milliyetçi) Sosyalizmine giden süreci anlatır. Kapitalizmin kaçınılmaz gelişiminin genişlemeci emperyalist savaşla sonuçlandığını gözler önüne serer. Silindir şapkalı burjuvaziden askeri mumyalara ve oradan da kurukafa kelebeklerine (ya da güveye) giden süreç, Marks'ın tarihsel determinizmine dayanan kapitalizme dem vurur. Dolayısıyla Hitler, Marksist teoriye göre, aşırı kapitalist üretimin kaçınılmaz sonu olarak gördüğü yayılmacı emperyal politikaları angaje etmek üzere istediği yere özgürce uçar, arkasındaki gamalı haçta yüzsüzlükle gösterilir. John Heartfield, politik tarihin alegorisini sunmak üzere, bir mit olarak değil, özünde var olan gerçek gibi doğa tarihini kullanır. Dalların, yaprakların ve böceklerin gölgelerinin yansımaları gerçek dünyaya ilişkindir, hayali değildir. Uğursuz bir işarete dönüşen kurukafa kelebeğinin doğal şeklini gösteren bu montaj, izleyiciye zaten var olan formların anlamını sunar. Benzerliğin, metamorfozun ve alegorinin bize sunduğu zevklerle eğlenirken John Heartfield, gerçek ve sanrıyı, doğa ve tarik arasındaki rolü artan siyasal bilincin hizmetine sunacak şekilde açıkla- makta ısrarlıdır (Kriebel, 2009: 78-80). ${ }^{6}$

Bu fotomontaj üzerine araştırma yapan Bio Art sanatçısı Suzanne Anker'in (1946) görüşü ise John Heartfield'ın Alman hükümetinin üyelerini üç biyolojik gelişim evresine koyduğu çalışmasında fotoğraftaki diyagramla gösterilmiş evrimin devamında Weimar Cumhuriyetini faşizmle birleştirdiği yönündedir. Hitler’in iktidara çıkışının kaçınılmaz oluşuyla ilgili Anker şu yorumu yapmıştır: "Burada başkalaşma doğal tarihle politik iktidarı bir araya getirir. Politikacı bir böceğe bağlanmıştır ve görsel bir dönüşüm, bir canavar yaratılmıştır” (Anker, 2000: 371). ${ }^{7}$

Anker, kolâj tekniğinde her hangi bir görüntünün bir diğerinin parçasıyla değiştirildiğini ve yeniden biçimlendirildiğini belirtir. Kolâj hilesi, filmin belli sahnelerini alarak bir araya getirmek gibi, zamanda ve uzamda birbirinden bütünüyle ayrışık unsurları birbirine ekler ve görünüşe göre gerçekle kurguyu kaynaştırır. Kolaj teknikleri, böylece, otantiklik (özgünbenzerlik), gerçeklik ve görsel olarak düzgülenmiş temsili sistemlerin doğasıyla ilgili sorular yönelterek, derin algısal etkiye sahip olmuşlardır. Anker'a göre; Heartfield'ın çalışması bir insan-hayvan melezi olarak hem doğaya aittir hem de doğa dışı (gerçeküstü) bir varlıktır. Uyumsuz oluşu rahatsız edicidir ancak etkili ve güçlü bir dönüşüm imgesidir. Bu yönüyle grotesk bir tavrı da özünde barındırır (Anker, 2000: 372-374).

Grotesk; gelişme süreci içinde saçmanın, gülüncün, çarpık olanın, hilkat garibesinin betimlenmesidir ve güzel sanatlarda yükselişi psikanaliz, fotoğraf, kitle iletişim araçları, bilimkurgu, kitle imha silahları ve sanal gerçeklik dâhil olmak üzere kültürel araçlar aracılığıyla yaygınlık kazanmıştır. Anker’a göre grotesk, kültürel olarak nefret uyandıran bir arka plana sahiptir; kullanımı ise, hızı artan bir teknolojik müdahale ile yaşam biçimlerinin manipüle edilmesi çağında kendini gösteren kaygı ve ikircikleri yansıtmaya devam etmektedir (Anker, 2011: 36). John Heartfield'ın çalışmalarının çoğuna olduğu üzere, bu yazının odağında bulunan "Başkalaşım” adlı fotomontaj çalışmasında da grotesk bir tavır gözlemlenmekte ve iç içe örülen kavramlarla arka planda aynı kaygıların varlığını duyumsanmaktadır. Sanatçı, görüntüsel metin boyutuna taşıdığı malzemelerle adeta oyun oynamakta, izleyiciyi şoke ederek, yapıtın içine çekmeye ve onu sorgulamaya yönlendirmektedir. 


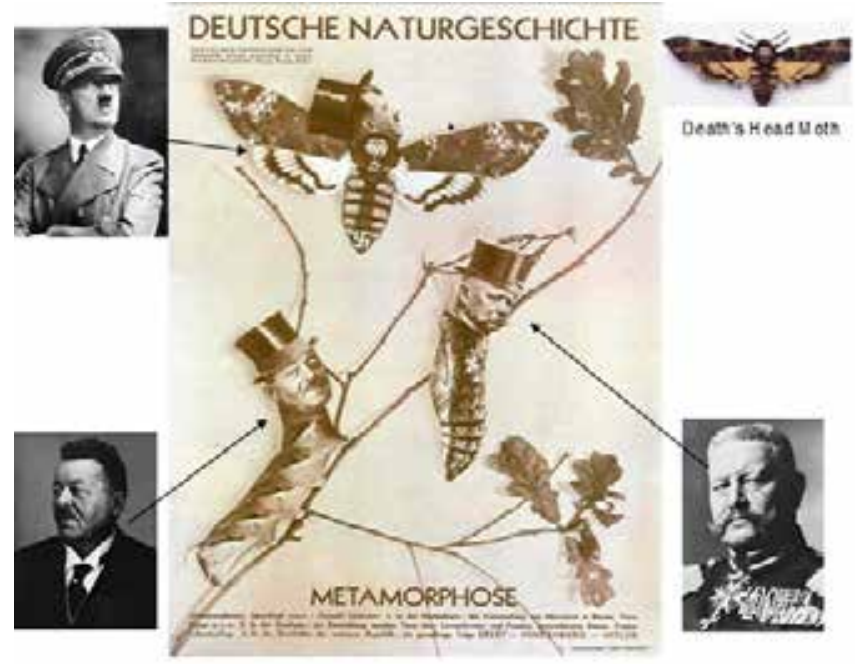

Resim 2. John Heartfield, Metamorphose. Heartfield'ın kurgusuna göre, politik tarihte Ebert- Hindenburg- Hitler'in, doğa tarihinde kurtçuk-krizalit-güveye dönüşümü (Anonim, 2008: 13)

Her söylem kendinden önce üretilmiş başka söylemlere mutlaka bir şeyler borçludur. Heartfield'ın Başkalaşım adlı fotomontaj çalışmasında da geçmişin izlerine rastlamak mümkündür. Günümüz postmodernist koşulları içerisinde ‘özgünlük' tartışılan bir kavram haline gelmiştir. Kimilerine göre özgünlük bir kuruntudan başka bir şey değildir. La Bruyére’in söylediği gibi: "Her şey daha önce söylenmiştir” (Aktulum, 2011: 452). Kubilay Aktulum'dan (2011: 76) öğrendiğimize göre: Bir sanatsal biçimi alıntılamak, yansılamak, taklit etmek, esinlenmek (bilerek) resimlerarasılık (interpicturalité) kavramının alt yapılarını oluşturur. Bir yapıtta başka bir sanatçının yapıtının tümünün ya da kimi kesitlerinin alıntılandığı durumlarda resimlerarasılıktan ya da ona eş değer bir söylem olan yeniden resmetmekten söz edebiliriz.

Bu fotomontajın kültürel arka plana yönelik yapılan başka bir araştırmada dönemin güncel yazınsal bir metni ile doğrudan ilişkilendirildiği görülmektedir. Heartfield çalışmasını 1934 yılında Prag'da bulunduğu dönemde oluşturmuştur. Bu araştırmaya göre Heartfield'ın Prag'da geçirdiği zaman ile sanatçı ve yazarlarla kurduğu ilişkiler göz önüne alındığında Çekoslovakya doğumlu Yahudi yazar Franz Kafka'nın (18831924) yapıtlarına aşina olduğu ve bu çalışmasını kurgularken onun aynı adlı yapıtından esinlendiği yönündedir. Bilindiği gibi Kafka'nın çalışmaları sıklıkla Dadaizm ile ilişkilendirilen Sürrealizmi de içermek üzere birçok edebi ve felsefi akımla bağlar kurmaktadır. Kafka'nın gerçeküstü bir kurgulamayla yazdığı ünlü ve etkileyici yapıtlarından biri olan söz konusu roman 1915 yılında Dönüşüm (Orijinali Alm. Die Verwandlung) adıyla yayınlanmıştır. Romana göre Başkahraman Gregor Samsa ailesinin sorumluluğunu üzerine aldıktan sonra bir sabah uyandığında kendisini bir böceğe dönüşmüş olarak bulur (Kafka, 2016: 11). Kafka'nın yapıtının ana temalarından biri Gregor Samsa'nın yabancılaşma ve suçluluk duyguları üzerinden yansıtılır. Diğer bir tema ise maddiyata bürünmek ve genel anlamda insanlığın kaybı olarak belirir. Heartfield'ın kendi söylemi ile vermeye çalıştığı da Alman Doğa Tarihinde metamorfoza yani dönüşüme uğrayan, maddiyata bürünmüş ve insanlığını kaybetmiş kişiler üzerinedir. Bu araştırmaya göre Heartfield söz konusu dönüşümü Kafka'nın hikâyesinde geçen böcek metaforuna gönderme yaparak maddiyata bürünmek ve insanlığın kaybı teması ile metaforik bir benzetme çağrıştırarak aktarmak istemiştir (Cuevas-Wolf, 2009: 342343). 8

Tam bu noktada, Kubilay Aktulum'un Metinlerarasılık/ Göstergelerarasılık adlı çalışmasında geniş kapsamlı bir biçimde değinmiş olduğu 'göstergelerarası alışverişler' olgusundan söz edilebilir. Aktulum’a (2011: 17) göre “...göstergelerarasılık, iki farklı gösterge dizgesi arasındaki (örneğin yazının resimle, resmin müzikle vb.) alışveriş işlemini, değişik gösterge dizgilerine ait yapıtlar arasındaki açık ya da kapalı ilişkileri belirtir”. Bu doğrultuda görünen o ki Heartfield kendi ideolojisini empoze etmek üzere Alman Doğa Tarihi'nde biyolojik bir gelişim evresini anlatan görsel bir sözcenin yanı sıra Kafka'nın yazınsal bir yapıtından esinlenerek farklı bir giydirme ile yeni bir söylem oluşturma yoluna gitmiştir. Kaldı ki söz konusu bütüncenin 20. yüzyılın başlarında kullanılmaya başlanmış olan ve teknik anlamda "kolaj ya da montaj" da denilen ayrışık unsurları bir bütün içerisinde yan yana getirmeye dayanan" bir hazır-yapım çalışması olduğu göz önünde bulundurulduğunda, ortaya çıkan üretimi metinsel olarak 'alıntı' veya 'metinlerarası gönderge' ile bağdaştırmak kaçınılmaz gözükmektedir. Yeri gelmişken eldeki yeni sözcenin 'kipseldönüşüm' olgusunu da barındırdığını eklemekte yarar var. Bu olguya dair Aktulum (2011: 450) aynı yapıtında şunları söyler: “Kipseldönüşüm, kurgusal bir yapıtın gösterim biçimine -anlatısal ya da dramatik- ve kipte yapılan değişikliğe verilen addır. Bir kipten başka bir kipe geçilirken oluşan değişiklikler, salt biçemsel olabileceği gibi uzamsal, söylemsel ve izleksel birçok alt değişikleri içeriyor olabilir”. Tıpkı, Heartfield'ın Başkalaşım (Metamorphose) adlı çalışmasında yer alan kurtçuk-krizalit-güve benzetmesinde olduğu gibi... 


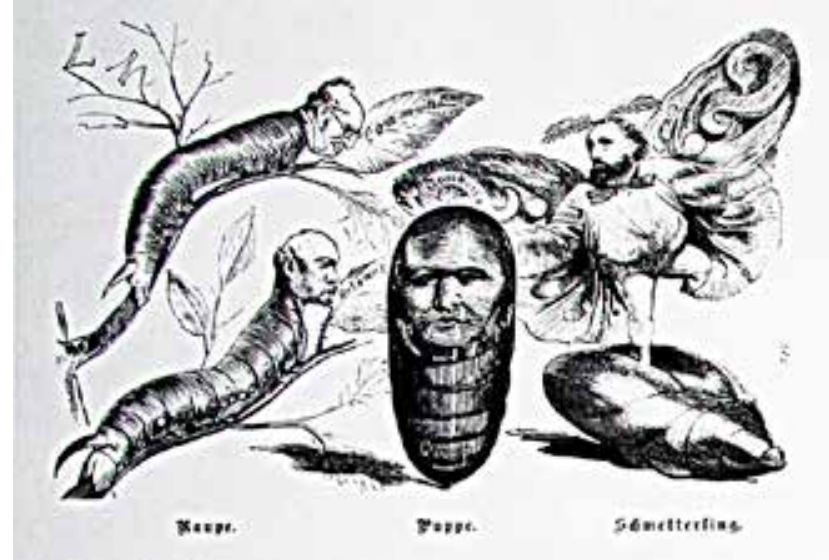

Resim 3. Anonim, "Başkan” (Der Praesident), karikatür. Kladderatsch (Kakafoni), 1881, sayı 6. Resimdeki yazılar: Raupe: Tırtıl (Kurtçuk), Puppe: Bebek,(Krizalit) Schmetterlig: Kelebek (Güve), (Maerz, 1993:106).

Yukarıdaki resim Kladderatsch (Kakafoni) olarak bilinen bir dergiden alınmış, anonim bir karikatürdür. Resimde Heartfield'ın çalışmasına benzer figürler göze çarpmakta. Heartfield'ın bu karikatürü görüp etkilendiğine ilişkin elimizde herhangi bir veri olmamasına rağmen her metnin kendinden önce gelen başka bir metinden alıntı olabileceği öngörüsünden hareketle ve konumuzun John Heartfield gibi daha önce üretilmiş bir takım sanatsal ve ikonolojik olguları kolaj ve fotomontaj tekniklerini kullanarak tekrar kullanıma sokan bir sanatçının üretimi olduğu göz önünde bulundurulduğunda elbette bu durumun olasılığı üzerinde düşünebiliriz.

Yapıtla ilgili edinilen deneyimlerin göstergebilimsel tablo ve çizelgelerle pekiştirilmesi önemlidir. Bu doğrultuda ilk olarak anlatı öğelerinin dizilimini zamandizinsel bir tablo üzerinde göstermek faydalı olabilir:

Tablo 1: Anlatı öğeleri

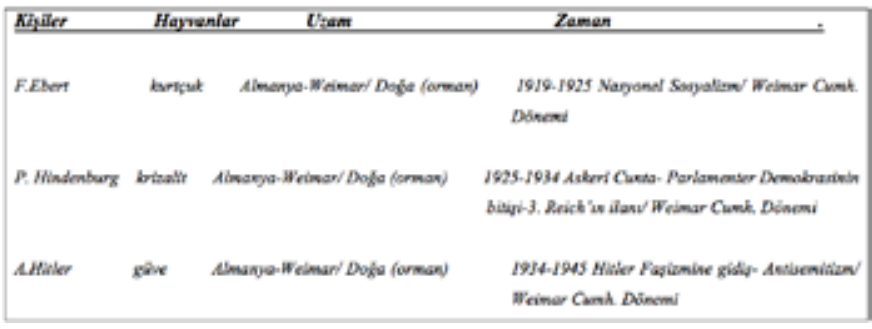

Görüldüğü üzere resmin sunduğu uzam kişi ve hayvanlar açısından ön planda verilmiştir. Zamansal açıdan aynı döneme gönderme yapıldığı anlaşılmaktadır. Bize aktarılmak istenen düşüncenin özünde, başkalaşım (metamorfizm) geçirmiş bir böceğin (güvenin) geçiş evresinin, o dönemin siyasi yöneticileri üzerinden verildiği olumsuz/esenliksiz bir benzet- me yatmaktadır. Sanatçı kurgusal alanda siyasal dönüşümün izini zararlı bir böceğin başkalaşım evresi ile ilişkilendirmiş izleksel anlamda Weimar Cumhuriyeti döneminde ülkeyi yönetenler, zararlı bir böcek benzetmesi yapılarak betimlenmeye çalışılmış ve vurgulanan betisellikler, derin yapıda / esenliksiz/ bir duruma bağlanmıştır. Doğayı gösteren kodlarla oluşturulmuş bir uzamda en üstte yüzünü göğe çevirmiş bulunan ve güve gövdesi içinde betimlenen Hitler bu duruşuyla yaptırımlarından vazgeçmeyeceğinin habercisi gibidir. Ortada yer alan P. Von Hindenburg ise gözleri kapalı tasvir edilerek olaylara karşı tepkisiz, bir bakıma artık hayatta olmadığı gösterilmek istenmiştir. Weimar Cumhuriyeti'nin kurucusu F. Ebert ise kurtçuk gövdesi ile yüzünü izleyen özneye çevirmiş, onların tepkilerini karşıdan izliyor gibidir. Sanatçı yapıtını tam bir Dadaist söylemle hem başkalaşım (metamorfoz) ritüeline gönderme yaparak ve dönüştürmek suretiyle düzenlemiş hem de içerik olarak yeni, biçim olarak /eski/ bilinen/ doğal/ bir eklemleme gerçekleştirmiştir. Bunu yaparken de geleneksel bir takım söylemlerden, mesela Kafka'nın aynı başlıklı bir öyküsünden yararlanmıştır. Diğer bir tablo, görsel düzenlemede yer alan “ön plan ve arka plan” olgularını açıklamak üzere oluşturulabilir:

Tablo 2: Plan

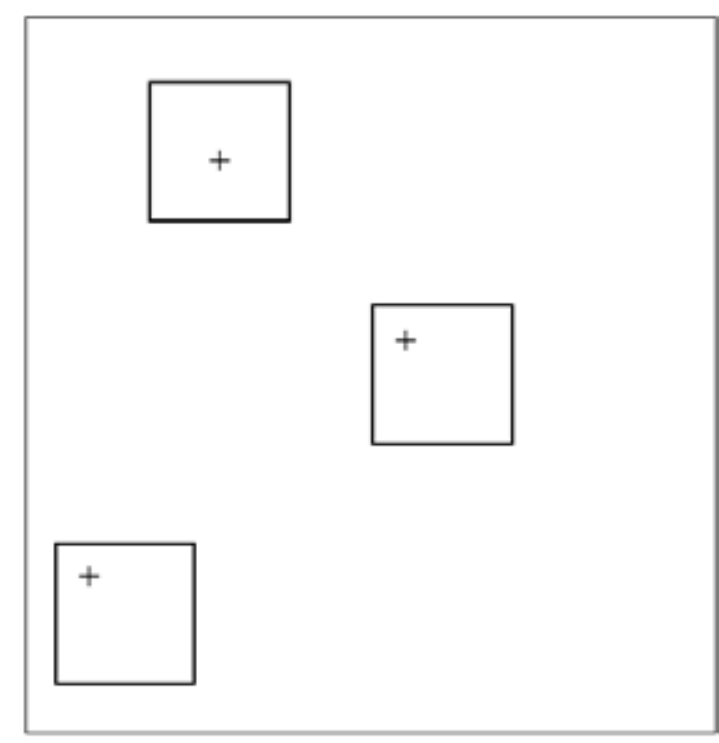

Ön Plan:Doğa uzamı:

/Tarafsız/Nesnel/Doğal/Tanrısal/

Arka Plan:

İlişkiler Uzamı ( Weimar Cumhuriyetine başkanlık eden yöneticiler ):

/Taraflı/Öznel/Yapay/İnsansal/ 
Bir diğer tabloyu, gösteren ve gösterilen olgularından yola çıkarak düzenleyebiliriz. Tam bu noktada, Fransız Göstergebilimci Jacques Fontanille'in (1948) görüşleri konumuzla ilişkilendirilebilir: Nedret Öztokat'ın, Fontanille'in söylemine dair aktardığı bilgilerin bir kısmı şöyledir:

Kavramsal sanatı, bir figürler bütününde örtülü ya da gizli kalmış bir boyutu ya da daha farklı bir boyutu ortaya çıkaran esteti bir edim olarak tanımlayan Fontanille, figürler bütününün en azından iki cephesi olacağını belirtir; bunlardan biri görsel sözcenin maddesel görünüşü, diğeri de sanatsal nesne boyutudur, bu iki cepheyi Saussure'den alacağımız bir benzetmeye dayanarak, kâğıdın ön ve arkası olarak görebiliriz. (...) Fontanille’e göre kavramsal sanatta şey ve nesnenin, bir başka deyişle, maddesel belirimi olan şey ve sanat nesnesinin ait olduğu iki düzenleme arasındaki ilişki çok özel niteliklidir. (...) Öte yandan kâğıdın önü ve arkasının bir yaprak kâğıtla olan ilişkisini de (figürler ve figürler bütünü arasındaki ilişkiye öykünerek) göz önüne alınca Fontanille, Duchamp'ın kavramsal sanat semiosis'inde figürün değil, kavramın süreklilik sağladığını, ‘şey’ ve ‘nesne’ boyutları arasındaki geçişi olanaklı kıldığını saptar: Şey’i ‘kavramsal nesne'ye dönüştüren kavram aslında ikisinin ortak oluş bedenidir. En azından ready-made için böyledir" (2008: 35-36).

Dada hareketi öncülerinden Marcel Duchamp'ın (18871968) nesne anlayışı (hazır-yapım/ready-made) ve hazır nesneleri kullanma biçimi, aynı hareket içinde yer alan ancak siyasi karakteri daha belirgin olarak göze çarpan Berlin Club Dada sanatçılarının hazır nesneleri kullanma istekliliğiyle büyük oranda örtüşür görünmektedir. Berlin Dada sanatçılarının öncülerinden John Heartfield için durum bundan farklı değildir. Tam bu noktada Fontanille'in saptamalarıyla özdeşleşen ve benzer bir izdüşümden hareketle sistematik bir tablo oluşturabiliriz:

Tablo 3: Fontanille'e göre 'şey’ ve 'nesne' ilişkisi

\begin{tabular}{|c|c|}
\hline "kes" ler & "sanatsal nesee" ler \\
\hline Kurtcesk & 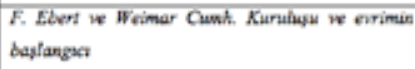 \\
\hline Erisulith & $\begin{array}{l}\text { P. v, Hindemburg ve Ena Ble Act lie minde yesi bir } \\
\text { ofryum }\end{array}$ \\
\hline Glive & 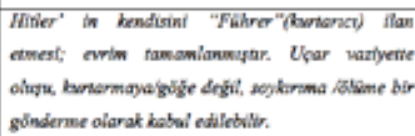 \\
\hline Mege of ofa & 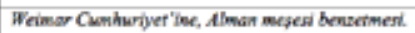 \\
\hline
\end{tabular}

Yapıtta anlamsal yoğunluğu aynı düzenlemede kaynaştıran, birleştiren bir unsur olarak yapıta adını da veren "başkalaşım" oluşumu ve evresi önemlidir. Metamorfoz, bu görsel söylemde metinsel bir birleştirici öğe olarak hem anlamsal, hem söylemsel işlev üstlenmiştir. Edimsel bir ideye bağlanması nedeniyle de kılgısal bir işlev daha üstlenmiş olur. Bu çoklu işlevselliğin yanı sıra tabloda "başkalaşım” bir süreç olarak işlemektedir. Kaldı ki, başkalaşım doğal süreç olarak da zamansallık içerir. Sanatçının başkalaşım (métamorphose) ritüelini bu denli yetkin bir biçimde kullanmış olması süreçleştirme işlemi açısından tabloda anlam üretmektedir. "Başkalaşım” izleğinin yapıtta görselleştirilmesi ikili bir işlem içermektedir. Bunlar sözcelem düzeyine ilişkin işlemlerdir:

Tablo 4: Sözce üstü işlemler

\begin{tabular}{|c|c|}
\hline $\begin{array}{l}\text { "Bapkalojem" } \\
\text { "Gốterme" }\end{array}$ & Gusaergelegninim \\
\hline "Anlatese" & Sbylemilessirim + Süreçiestinin \\
\hline
\end{tabular}

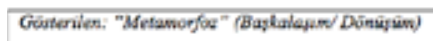

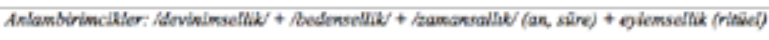

Son olarak izleksel yapı, şöyle bir tablo yardımı ile daha anlaşılabilir hale getirilebilir:

Tablo 5: İzleksel yapr

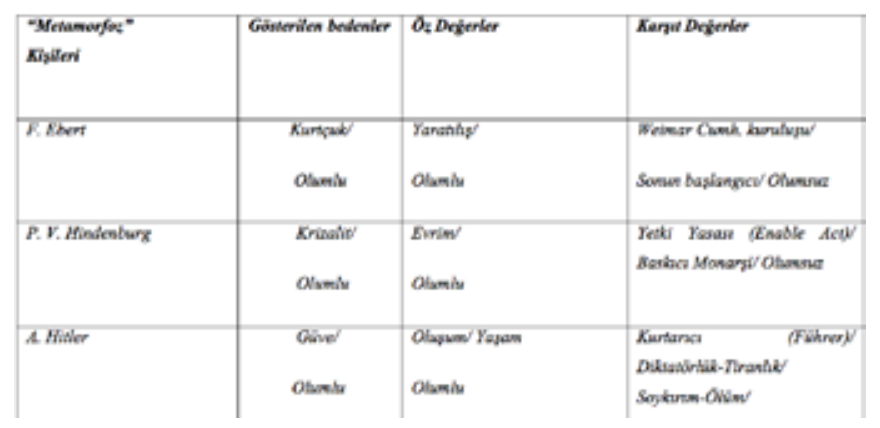

Montajda ön ve arka plan düzenlemeleri arasındaki gerilim belirgin olarak göze çarpmaktadır. İzleksel değer yapısı olarak uzlaşma kavramı değil, gerilim ve çatışma söz konusudur. Olumsuz bir dönüşümün anlatıldığı montaj resim, ön planda ve arka planda gösterilen iki farklı uzamın, başkalaşımın gerçekleştiği aynı uzam olması sebebiyle hem bilişsel hem de tutkusaldır.

\section{Sonuç:}

Sanat yapıtlarından reklâm afişleri ve gazete tasarımlarına 
kadar tüm görsel nesnelerin oluşturulması insani kurgularla olasıdır. John Heartfield kitle iletişimi bağlamında son yüzyılın en önemli sanatçılarından biridir. Görsel tasarımlarının her biri sınıf hegemonyasının prototipidir ve yapıtlarının neredeyse tümü onlara eklemlediği sloganların da yardımıyla kendi ideolojik tutumunu iletmeye yönelik çarpıcı bir bildiriyi barındırır. Belirtmek gerekir ki John Heartfield yapıtlarını kurgularken tümüyle ideolojik düşüncenin taşınması veya yüceltilmesini amaç edinir. Gerçekte tarihsel süreçler boyunca özellikle siyasal tarih resimlerinde, siyasi bir kişiliği ya da olguyu betimleyen heykel ve mimarilerde bu duruma sıkça rastlamak olasıdır. Politik fotomontaj, başını John Heartfield'ın çektiği yirminci yüzyılın en çok rağbet gören sanat yöntemlerinden biri olmuştur. Bu konuda dünyada öne çıkan başka sanatçılar da vardır: Kaethe Kollwitz (1867-1945), George Grosz (18931959), Rudolf Schlichter (1890-1955), Alexandr Rodchenko (1891-1956), László Moholy-Nagy (1895-1946), El Lissitzky (1890-1941), Gustav Klutsis (1895-1938), Herbert Bayer (1900-1985), Gottfried Kirchbach (1888-1842), Otto Baumberger (1889-1961), Mihaly Biro (1886-194) ve Willibald Krain (1886-1945) bu sanatçılara örnekler olarak verilebilir. Öte yandan günümüzde bir kısım sanatçı tarafından bu türden çalışmaların hali hazırda yapıldığı görülmektedir. Ne var ki bugüne kadar politik imgelemi sanat aracılığıyla dolanıma sokan Heartfield'dan daha keskin bir sanatçı yoktur (Bostancı, 2018: 227).

John Heartfield'ın çalışmaları, çağdaşları Erwin Piscator (1893-1956) ve Bertolt Brecht'in (1898-1956) çalışmalarında olduğu gibi, güncel nesneleri göstermeleri ve insan ihtiyaçlarının modern medya teknikleri ve toplu yaklaşımlarla sanatsal ifadeye doğru yönlendirilmesi amacını güden çabaların ürünleridir. John Heartfield fotoğrafta 'fakirin resmini' kullanmış ve AIZ ile resimlerini sömürülen halka ulaştırmıştır. Çalışmaları sosyal elitin beğenisi için hedeflenmemiştir, daha çok kitlelerin hayatlarının etkilenmesi hedeflenmiştir. John Heartfield bu yönüyle sanatçıya yeni bir rol biçmiştir. John Heartfield'ın yeteneği sayesinde fotomontaj, Weimar Almanyasında politik sanatın önemli bir unsuru haline gelmiştir. Ayrıca İngiliz yazar, çevirmen ve kültür tarihçisi John Willet'in (1917-2002) söylediği gibi, yapıtları Weimar kültürünün "yapıcı vizyonudur" (Kay, 1996: 41). ${ }^{9}$

Berlin Dada Grubunun önde gelen simalarından biri olan John Heartfield, 1920'li yılların Berlin Avangart dünyasının tanınmış bir kişiliğidir. Üyesi olduğu Alman Komünist
Partisi'nin, Dada yapıtlarını 'burjuva yozlaşması' olduğu gerekçesiyle reddetmesine ve Avangart sanat ile köktenci komünizm arasındaki bu ihtilâfa rağmen yalına kaçmadan ve fotomontaj ilkelerinden ödün vermeden çalışmalarını sürdürmüş̧ür. Heartfield'ın oldukça geniş bir ekip çalışması ile oluşturmuş olduğu işleri, üzerinde oldukça ince düşünülmüş, zengin ayrıntılarla ve dikkat çekici imgelerle donatılmış, kendi politik duruşunu söylemleştirdiği çarpıcı bir sanat yapıtı niteliğindedir. Sanatçı, toplumun değer yargılarını, yaşam biçimi ve kültürel birikimini kapalı bir şekilde eleştirmektedir. Heartfield'ın söylemlerinde genellikle iğneleyici bir tutumun egemen olması ve zaman zaman şiddet içermelerine karşılık, buna neden olan toplumsal-siyasal ve kültürel etkenler göz ününde bulundurulduğunda, amacının barışa yönelik ve in sani olması, sanatçının karşıtıkları kullanarak anlam üretme yetisinin birer göstergesi olarak değerlendirilebilir.

Bu çalışma ile tarihsel bir süreç içinde 20. yüzyıla damgasını vurmuş bir sanatçının fotomontaj tekniklerinin uygulayıCıSı ve öncülerinden biri olarak kabul edilen John Heartfield'ın görsel sözcelerinden birini, metaforik yapılanması üzerinden ve imgelerin anlamsal gizleri aracılığıyla çözümlemek amaçlanmıştır. Bunu yaparken göstergebilimin sağladığı olanaklara özde bağlı kalınmış ve yeri geldiğinde "metinlerarası/ göstergelerarası” ilişkiler kurarak çalışmanın sağlamlaştırılmasına çalışılmıştır. Bu aynı zamanda politik bir söylem aracı olarak sanatsal imgelemi John Heartfield örneği üzerinden göstergebilim yöntemleri aracılığı ile okuma edimidir.

Bugün John Heartfield'ın yapıtlarının içerdiği politik mesajlar ya da ideolojik tutumundan çok grafik yaratıcılığı ve estetik amaçları üzerine düşünebiliriz. Bu çalışmasında olduğu gibi sanatçının içinde bulunduğu faşist iktidara yönelik şiddetli saldırılarının nesneleri artık sanatsal bir sorgulamanın konusu haline gelemeyecek olsa da yapıtlarının sanat olarak hala nasıl yaşayabildiğini görmek şaşırtıcıdır. Yine de onun asıl amacının Naziler ile toplumsal adaleti ve insan haklarını tehlikeye atan diğer herkese karşı uyarıları yaygınlaştırmak olduğu göz ardı edilmemelidir. Failleri ve mekânları değişmiş olsa bile John Heartfield'ın işaret ettiği kötülükler militarizm, savaş vurgunculuğu, etnik kırım ve temizlik, politik yozlaşma ve komplo, bugün de varlığını sürdürmektedir. 


\section{Notlar}

1- John Heartfield, 1891'de Berlin'de Helmut Herzfeld adı ile dünyaya gelmiştir. Birinci Dünya Savaşı sırasında Sanat ve El Sanatları Okulu'ndaki (Kunts und Handwerkerschule) eğitimini yarıda bırakarak savaşa katılmış; savaş sırasında gördüğü adaletsizlikler ve insanlık dışı eylemler karşısında uydurma bir sinir hastalığını gerekçe göstererek ordudan ayrılmıştır. 1916'da savaşı protesto etmek ve o sıralarda Almanya'nın geneline yaygın olan İngiliz karşıtığına tepki vermek amacıyla adını İngilizceleştirerek John Heartfield olarak değiştirmiştir (Herzfelde, 1986: 17).

2- İlgili yazıyı çevrimiçi görüntülemek için bkz. https://books.google.com.tr/books/reader?printsec=frontcover\&outp $u t=$ reader\&id $=X b 9 D C g A A Q B A J \# v=$ onepage $\& q \& f=$ false Erişim tarihi: 14.03.2018.

3- Fransız akademisyen, sosyolog ve antropolog Gilbert Durand (1921-2012) imgeyi, düşselliğe ilişkin terimler arasında sayar. Ona göre bilinç, dünyayı zihinde canlandırmak için iki ayrı yola başvurur; biri doğrudandır ve basit duyu ile kolayca algılanır, diğer ise dolaylıdır ve herhangi bir nedenden ötürü duyuda canlı bir şekilde görünmez. Var olmayan bir nesne söz konusudur ve bilinç bunu ancak imge aracılığıyla algılar. Durand imgenin gösterilenden ebediyen yoksun işaretlerden oluştuğunu belirtir ve bu uzak işaretin sembolden başka bir şey olmadığını söyler (Durand, 1998: 7-8).

4- İlgili bildiriyi görüntülemek için bkz. http://classicsvic. files.wordpress.com/2014/01/hawesvol21.pdf Erişim tarihi: 14.03.2018.

5- Bu yazıya konu olan "Başkalaşım” (Metamorphose) adlı fotomontaj çalışmasının 16 Ağustos 1934 tarihinde yayımlandığı gazete, Resimli İşçi Gazetesi (Die ArbeiterIllustrierte-Zeitung), kısaca AIZ olarak bilinir ve ülkenin yaygın medya gruplarıyla rekabet içerisinde olan komünizm savunucusu haftalık bir yayındır. 1930 yılı itibariyle Heartfield, fotomontajlarını düzenli olarak merkezi Berlin'de bulunan bu gazetede yayımlamaya başlamıştır (Evans, 1992:9). İlgili kitabı görüntülemek için bkz. https://www.amazon.com/John-Heartfield-AIZ-VI-1930-38/ dp/1878607286\#reader_1878607286 Erişim tarihi: 14.03.2028. Bu çalışma, Heartfield'ın SS subaylarından kaçarak sığındığı Prag'da bulunduğu süre içerisinde üretilmiştir.

6- İlgili makaleyi görüntülemek için bkz. https://cora.ucc. ie/bitstream/handle/10468/215/Kriebel_HeartieldSuture. pdf?sequence=1\&isAllowed=y Erişim tarihi: 14.03.2018.

7- İlgili makaleyi görüntülemek için bkz. https://muse.jhu. edu/article/608267/pdf Erişim tarihi:14.03.2018.

8- İlgili makaleyi görüntülemek için bkz. https://www.academia.edu/7789725/John_Heartfield_s_Insects_and_the_ Idea_of_Natural_History Erişim tarihi: 14 .03.2018.

9- İlgili makaleyi görüntülemek için bkz. https://lh.journals. yorku.ca/index.php/lh/article/view/6982/6166 Erişim tarihi: 14.03.2018.

\section{Kaynakça}

Aktulum, K. (2011). Metinlerarasılık/ Göstergelerarasılık. Ankara: Kanguru Yayınları.

Anker, S. (2000). "Gene Culture: Molecular Metaphor in Visual Arts" Leonardo, Vol. 33 No. 5. The MIT Press: Cambridge. [371- 375]

Anker, S. (2011). “Temelde İnsan- Çağdaş Sanat ve Nörobilim”. Sergi kataloğu yazısı. Çeviren: Kemal Atakay. İstanbul: Pera Müzesi Yayınları. [23-53]

Anonim (2008). "John Heartfield VS. NAZI GERMANY" adlı sergi broşürü. Akron Sanat Müzesi, Akron: ABD. 30 Ağustos-30 Ekim 2008 tarihinde Akron Sanat Müzesi'nde düzenlenmiş olan "John Heartfield VS. NAZI GERMANY” adlı serginin eği timci rehber broşürü.

Barthes, R. (1979). Göstergebilim İlkeleri. Cevirenler: Berke Vardar-Mehmet Rifat. Ankara: Kültür Bakanlığı Yayınları, 337.

Barthes, R. (1988). Anlatıların Yapısal Çözümlemesine Giriş. Çevirenler: Mehmet- Sema Rifat. İstanbul: Gerçek Yayınevi.

Barthes, R. (1993). Göstergebilimsel Serüven. Çeviren: MehmetSema Rifat, 2. Baskı. İstanbul: YKY.

Bostancı, M. (2018). John Heartfield ve Politik Fotomontajları. İstanbul: Mimar Sinan Üniversitesi Yayınları.

Bostancı, M. (2012). John Heartfield ve Nesne Yorumu. Yayımlanmamış Yüksek Lisans Tezi. İstanbul: Işık Üniversitesi, SBE.

Brunel, P. (2004). Le Mythe de la Métamorphose. Librairie. Paris: Jose Corti.

Cömert, B. (1999). Mitoloji ve İkonografi. 2. Baskı. Ankara: Ayraç Yayınları.

Cuevas-Wolf, C. (2009). "John Heartfield's Insects and the 'Idea' of Natural History", Elective Affinities: Testing Word and Image Relationships. Word \& Image Interactions 6. Editörler: Catriona MacLeod, Ve'ronique Plesch, Charlotte SchoellGlass. NY-Amsterdam: Radopi. [337- 353]

Durand, G. (1998). Sembolik İmgelem. Çeviri: Ayşe Meral. İstanbul: İnsan Yayınları.

Evans, D. (1992). John Heartfield AIZ/ VI 1930-38. NY: Kent Fine Art Inc.

Günay, V. D. (2012). "Görsel Göstergebilim ve İmgenin Anlamlandırılması”, Görsel Göstergebilim. İstanbul: Es Yayınları. [11-54]

Hawes, G. (2008), "Metamorphosis and Metamorphic Identity: the Myth of Actaeon in works of Ovid, Dante and John Gower”, Iris, vol. 21, pp. 21-42.m

Herzfelde, W. (1986). John Heartfield, Leben und Werk. Dargestellt von seinem Bruder Wieland Herzfelde. Dresden: VEB Verlag Der Kunst.

http://classicsvic.files.wordpress.com/2014/01/hawesvol21.pdf Erişim tarihi: 14.03.2018. 
https://books.google.com.tr/books/reader?printsec=frontcove r\&output=reader\&id=Xb9DCgAAQBAJ\#v=onepage $\& q \& \mathrm{f}=\mathrm{fal}$ se Erişim tarihi: 14.03.2018.

https://cora.ucc.ie/bitstream/handle/10468/215/Kriebel_ HeartieldSuture.pdf?sequence $=1$ \&isAllowed=y Erişim tarihi: 14.03.2018.

https://h.journals.yorku.ca/index.php/lh/article/ view/6982/6166 Erişim tarihi: 14.03.2018.

https://muse.jhu.edu/article/608267/pdf Erişim tarihi: 14.03.2018.

https://www.academia.edu/7789725/John_Heartfield_s_Insects_ and_the_Idea_of_Natural_History Erişim tarihi: 14.03.2018.

https://www.amazon.com/John-Heartfield-AIZ-VI-1930 38/ dp/1878607286\#reader_1878607286 Erişim tarihi: 14.03.2018.

Kafka, F. (2016), Dönüşüm, 5. Basım, Çeviri: Alper Hasanoğlu, Remzi Kitabevi A.Ş.:İstanbul.

Kay, C. (1996) "Art and Politics in Interwar Germany The Photomontages of John Heartfield", Left History an InterdisciplinaryJournal ofHistorical Inquiryand Debate, Vol.4 No.2. [11-50]

Kıran, Z. -Kıran, A. (2001). Dilbilime Giriş. İstanbul: Seçkin Yayıncılık.

Kriebel, T.S. (2009). John Heartfield Mass Medium, "Manufacturing Discontent: John Heartfield's Mass Medium”, New German Critique 107, Vol. 36, No. 2. [53-88]

Öztokat, N. (2008). “Görsellik, Retorik, Göstergebilim” Dipnot Sanat ve Tasarım Yazıları, sayı 3. İstanbul: MSÜ. [30- 37]

Panofsky, E. (1995). Gotik Mimarlık ve Skolastik Felsefe. Çeviri: Engin Akyürek, 2. Baskı, İstanbul: Kabalcı Yayınevi.

Panofsky, E. (1995a). İkonografi ve İkonoloji. Çeviri: Engin Akyürek, İstanbul: Afa Yayıncılık A.Ş.

Rifat, M. (2008). XX. Yüzyılda Dilbilim ve Göstergebilim Kuramları. 1.Cilt, Tarihçe ve Eleştirel Düşünceler, 4. Baskı. İstanbul: YKYYayınları.

Zervigon, A. M. (2007). “Agitated İmages: John Heartfield \& Germen Photomontage 1920-1938” başlıklı sergi broşürü. The Wolfsonian, LA: Florida International University.

\section{Görsel Kaynaklar}

Resim 1. Pachnicke, Peter. \& Honnef, Klaus (1992). John Heartfield, s. 165 . New York: Harry N. Abrams, Inc.

Resim 2. Akron Sanat Müzesi'nin 30 Ağustos-30 Ekim 2008 tarihinde düzenlenmiş olan "John Heartfield VS. NAZI GERMANY” adlı sergi broşüründen alınmıştır.

Resim 3. Maerz, Roland (1993). John Heartfield, s.106. Leipzig: Edition Leipzig. 